\title{
Index of manuscripts ${ }^{742}$
}

Manuscript of the Abhayapaddhati (aka Buddhakapālamahātantrațīkā) (see AP), National Archives, Kathmandu, 5/21 - 34, 63, 66-67, 83, 103-104, 118-125, 247, 289, 348

Manuscript of the Abhisamayālan்kārālokā (see AAĀ), National Archives, Kathmandu, 3/738 31, 59, 67, 103-104, 117-125, 182, 243, 249, 273, 276, 281, 283, 288, 291-292, 298, 300, 346

Manuscript of the Anāvilatantra (see AT), General Library, University of Tokyo, Tokyo, MF14 63 $014-37,65-67,81,90-91,118-125,138-139,350$

Manuscript of the Antarvyāptisamarthana, National Archives, Kathmandu, 3/364 - 109, 116

Manuscript of the Aștasāhasrikā Prajñāparamitā, Cambridge University Library, MS Add.866 188, 192-193, 197, 297

Manuscript of the Așțasāhasrikā Prajñāparamitā, Kaiser Library, Kathmandu, 18, 114-115, 146, 193, 197

Manuscript of the Aștasāhasrikā Prajñāpāramitā (see AșP $\mathrm{P}_{1}$ ), National Archives, Kathmandu, 5/195 - 27, 54, 81, 83-84, 91, 97, 102, 108, 113, 142-144, 165-166, 239, 249, 281, 288, 336

Manuscript of the Aștasāhasrikā Prajñāpäramitā (see AșP $\mathrm{P}_{2}$ ), National Archives, Kathmandu, $3 / 359-28,55,87,241,249,342$

Manuscript of the Aștasāhasrikā Prajñāpāramitā, National Archives, Kathmandu, 5/76 - 195, 197,241

Manuscript of the Aștasāhasrikā Prajñāparamitā, NGMPP E 2122/7 - 192-193, 197

MTM of the Bālārkastutițīkā, Daśakrodhāgnisalokasañgraha, Pañcatathāgatastuti, Kaiser Library, Kathmandu, 45 - 148-149, 164-165

MTM of the Bhaișajyagurusūtra and the Vajracchedikā Prajñāpāramitā Sūtra, Schøyen collection, MS $2385-79$

Manuscript of the Bodhisattvabhūmi, Cambridge University Library, MS Add.1702 - 194, 197

MTM of the Bodhicaryāvatāra, Āryavalokiteśvarastotra etc., Kaiser Library, Kathmandu, 127 144-146

Manuscript of the Bṛhaccūrṇivyākhyā (see BCV), British Library Board, London, Or. $1386-40$, 72-73, 88, 106, 128, 132, 134, 205-206, 276, 286-288, 356

Manuscript of the Cändravrtti, National Archives, Kathmandu, 5/729 - 99

Manuscript of the Catușpițhanibandha (see CPN), Kaiser Library, Kathmandu, 134 - 35, 63, 66-67, 83, 103, 118-125, 246, 249, 271, 288-289, 349

Manuscript of the Catușpițhanibandha, National Archives, Kathmandu, 4/20 - 105

Manuscript of the Ḍākinīvajrapañjarațippaṇi (see ḌVPṬ), Kaiser Library, Kathmandu, 230 - 34, $62,66-67,83,103-104,118-125,348$

742 N.B. this index lists only the manuscripts that appear in the 'main text' and therefore excludes the many other manuscripts and inscriptions referred to in the footnotes. 
Manuscript of the Dānadharma (see DDh), National Archives, Kathmandu, 1/1321 -24, 52, 83, 99, 237, 249, 327

Manuscript of the Dìrghāgama - 186-187, 197

Manuscript of an 'early commentary', Schøyen collection, MS 2373/1- 76

Manuscript of the Gaṇdavyūha, National Archives, Kathmandu, 3/284 - 159

Manuscript of the Gaṇdavyūha, National Archives, Kathmandu, 5/75 - 160

Manuscript of the Gaṇavyūha, National Archives, Kathmandu, 3/258 - 161, 165-166

Manuscript of the Guṇavatī (aka Mahāmāyāțīkā) (see GV), Kaiser Library, Kathmandu, 226 31, 59, 66-67, 81, 103-104, 118-125, 243, 270, 288, 346

Manuscript of the Hamsayāmala (see HY), National Archives, Kathmandu, 1/1076 -24, 51, 83, $102,108,110-111,326$

Manuscript of the Haravijayamahākāvya (see HVM), Jinabhadrasūri Grantha Bhaṇụāra, Jaisalmer, 408 - 38, 69, 72-73, 89, 106, 126-128, 130, 134, 203, 206, 274-275, 288, 353

Manuscript of the Harivamía (see $\mathrm{HV}_{1}$ ), National Archives, Kathmandu, 1/910 - 23, 51, 57, 74, $83,87-88,90-91,135,236,249,255,259,261,325$

Manuscript of the Harivam̧śa (see $\mathrm{HV}_{2}$ ), National Archives, Kathmandu, 1/455 - 27, 54, 83-84, 87-88, 92-93, 97, 102, 133, 240, 249, 338

Manuscript of the Herukābhyudayapañjikā (aka Katipayākșarā) (see HAP), Kaiser Library, Kathmandu, 229 - 32, 60, 66-67, 103, 105, 118-125, 245, 347

Manuscript of the Hevajrapañjikā (aka Ratnāvalī) (see HP), Kaiser Library, Kathmandu, 231 35, 64, 66-67, 103, 118-125, 244, 249, 289, 349

Manuscript of the Hevajratantrațīā (aka Șațsāhasrikā) (see HTṬ), Kaiser Library, Kathmandu, $128-36,65-67,74,83,91-92,118-125,139,144,274,288-289,292-293,300,350$

Manuscript of the Jītakalpasūtra/Jītakalpacūrṇī (see JKS/C), British Library Board, London, Or. $1385-39,70,72-73,88,106,128,131,134,275,285,287-288,355$

Manuscript of the Kalyānakāmadhenūvivaraṇa, National Archives, Kathmandu, 3/363 - 112

Manuscript of the Kāraṇ̣avyūha/Ușnịșavijayadhāriṇī (see KV/UVDh), National Archives,

Kathmandu, 3/359-21, 49, 57, 89, 95-96, 132, 134, 249, 317

Manuscript of the Khandakhādya, Kaiser Library, Kathmandu, 233- 92

Manuscript of the Kiranatantra (see KT), National Archives, Kathmandu, 5/893 - 11, 20, 48, 57, $83,85-86,88,91,94,169-170,179,223,231,269,272,288,316$

Manuscript of the Kulālikāmnāyatantra, National Archives, Kathmandu, 5/877 - 110

Manuscript of the Laghutantrațīkā (see LTṬ), Kaiser Library, Kathmandu, 225 - 32, 61, 66-67, 83, 103-105, 118-125, 245, 289, 347

Manuscript of the Lañkāvatāra, National Archives, Kathmandu, 3/610 - 155

Manuscript of the Lalitavistara, National Archives, Kathmandu, 4/9-154, 165

Manuscript of the Niśvāsatattvasaṃhitā (see NTS), National Archives, Kathmandu, 1/277 - 19, $47,57,81,83,85,89-91,93,250,315$

Manuscript of the Nìtisārapañjikā (Jayamañgalā), Kaiser Library, Kathmandu, 77 - 115-116 
Manuscript of the Pañcarakșā (see PR), Cambridge University Library, MS Add.1688 - 13, 30, $58,66-67,73-74,83,85-86,92,98,105,170-171,345$

Manuscript of the Pañcarakșā, Kaiser Library, Kathmandu, 108 - 150-151

Manuscript of the Pañcarakșā, Kaiser Library, Kathmandu, 105 - 151-152

Manuscript of the Pañcarakșā, National Archives, Kathmandu, 1/1114 - 150

Manuscript of the Pārameśvaratantra (aka Paușkarapārameśvara) (see PT), Cambridge University Library, Add.1049 - 17, 46, 57, 83, 86, 88, 93, 309

Manuscript of the Pāramitāsamāsa, National Archives, Kathmandu, 5/145 - 103-104, 118-125

Manuscript of the Prajñāpāramitā, National Archives, Kathmandu, 4/215 - 157, 166

Manuscript of the Praśnavyākarana (see PV), National Archives, Kathmandu, 4/149 - 39, 70, $73,89,106,127-128,130-131,134,168,354$

Manuscript of the Ratnakaraṇdikā, Kaiser Library, Kathmandu, 522 - 171-172

Manuscript of the Saddharmapuṇarīka, Cambridge University Library, MS Add.2197, 10, 111113, 191, 197

Manuscript of the Saddharmapuṇdarīkasūtra (see SDhPS), National Archives, Kathmandu, $3 / 678-28,55,58,83-84,97,105,143-144,165,185-186,189-191,197,240,249,341$

Manuscript of the Saddharmapuṇarīkasūtra, National Archives, Kathmandu, 4/217 - 158

Manuscript of the Sādhanamālā, National Archives, Kathmandu, 3/387 - 148

Manuscript of the Sādhanasamuccaya (see SS), Cambridge University Library, MS Add.1648 $29,56,83,103,242,267,278,282,288,343$

Manuscript of the Samādhirājasūtra, National Archives, Kathmandu, 3/611 - 156, 165

Manuscript of the Sampuțatantrațīkā (aka Prakaraṇārthanirṇaya) (see STṬ), Kaiser Library, Kathmandu, 228 - 33, 61, 66-67, 83, 103, 118-125, 173, 246, 347

Manuscript of the Sarvakulatattvasiddhividhivistaratantra, Kaiser Library, Kathmandu, 143 195, 197

Manuscript of the Sarvaprakaranasangraha, Kaiser Library, Kathmandu, 36 - 282

Manuscript of the Śatasāhasrikā Prajñāpāramitā, Royal Library, Copenhagen (Det Kongelige Bibliotek), Nepal 175A - 112-113

MTM, Schøyen collection, MS $2378-77$

Manuscript of the Siddhasārasaṃhitā (see SSS), National Archives, Kathmandu, 7/4 - 26, 53, 81, 83, 91-92, 95, 101, 103, 334

Manuscript of the Śivadharma corpus, Cambridge University Library, MS Add.1645 -253

Manuscript of the Śivadharma corpus, National Archives, Kathmandu, 1/1261 - 94-96, 100, 102

MTM of the Sugatāvadāna, Vasudhārādevīvratakathā, National Archives, Kathmandu, 5/235 152

MTM of the Sugatāvadānādisangraha, National Archives, Kathmandu, 4/1381 - 153, 162

Manuscript of the Suśrutasaṃhitā/Suśrutanighaṇtu (see SS/N), Kaiser Library, Kathmandu, $699-18,46,57,81,83,86-88,90-92,94,136,252,266,268,272,280,288,292,294$, 300,310

Manuscript of the Skandapurāna (see $\mathrm{SP}_{1}$ ), National Archives, Kathmandu, 2/229 - 16, 45, 57, $73,78,83,86,88,95-96,98-100,207-209,215,218-219,231,234,249,255,259,261$, $272,288,305$ 
Manuscript of the Skandapurāna (see $\mathrm{SP}_{2}$ ), National Archives, Kathmandu, 1/831 - 19, 47, 57, 73, 78, 85-91, 95, 99-102, 108-109, 219, 231, 235, 249, 255, 257, 259, 261, 272, 280, 288,313

Manuscript of the Skandapurāna (see $\mathrm{SP}_{3}$ ), Bodleian Library, Oxford, MS Sansk a. 14 (R) - 21, 49, 57, 81, 83-85, 88-89, 93-96, 98-102, 108-110, 174-179, 209-214, 235, 249, 318

Manuscript of the Skandapurāna (see $\mathrm{SP}_{4}$ ), National Archives, Kathmandu, 4/2260 - 22, 50, 57, 83-85, 96, 209-214, 268, 273, 288, 292, 295-297, 300, 323

Manuscript of the Svacchandalalitabhairavatantra, National Archives, Kathmandu, 1/224 105

Manuscript of the Tantrasadbhāva (see $\mathrm{TS}_{1}$ ), National Archives, Kathmandu, 5/445 - 25, 52, $81,83,103,238,249,280,288,328$

Manuscript of the Tantrasadbhāva (see TS 2 ), National Archives, Kathmandu, 1/363 - 29, 56$57,83,98,267,344$

Manuscript of the Tattvasamgraha (see TSa), Jinabhadrasūri Grantha Bhaṇḍara, Jaisalmer, 377 -11-12, 37, 68, 72-73, 87, 90, 106, 128-129, 134, 198, 206, 274, 284, 288, 351

Manuscript of the Tattvasaṃgrahapañjikāvṛtti (see TSPV), Jinabhadrasūri Grantha Bhaṇḍāra, Jaisalmer, $378-12,38,69,73,85,106,126,128-130,134,184,201,206,226,231,352$

Manuscript of the Tattvopaplavasiṃha (see TUS), Hemacandrācārya Jaina Jñānamandir, Patan, $178(2)-40,71-73,88,106,128,131-132,134,229,231,275,286-288,355$

Manuscript of the Yogasārasamuccaya, National Archives, Kathmandu, 5/7244 - 86

Manuscript of the Yogayājñavalkya (see YY), National Archives, Kathmandu, 5/696 - 22-23, $50,57,90-91,95,324$

Manuscript of the Vajrāvalī, National Archives, Kathmandu, 5/84-99

Manuscript of the Vinayavastvāgama, GBM 1050 - 187-188, 197

Manuscript of the Vișnudharma (see VDh), National Archives, Kathmandu, 5/344 - 25, 53, 58 , 83, 86, 90-93, 97, 173, 181, 329

Manuscript of the Viṣnudharma, National Archives, Kathmandu, 1/1002/1 - 85

Manuscript of the Viṣnudharma, National Archives, Kathmandu, 4/1389 - 97

Manuscript of the Viṣnudharma, National Archives, Kathmandu, 4/766 - 115

Manuscript of the Viṣnudharma, Kaiser Library, Kathmandu, 2 - 86, 102, 105

Manuscript of the Vìtaśokāvadāna, Schøyen collection, MS 2380/6 - 78 